\title{
A História da Ciência no PNLD 2018: o Princípio de Arquimedes como estudo de caso
}

Juliana Mesquita Hidalgo ${ }^{1}$

Universidade Federal do Rio Grande do Norte

Daniel de Medeiros Queiroz ${ }^{1}$

Atheneu Norte-Riograndense

Mara Cristina Júlio de Oliveira ${ }^{1}$

Mestranda em Ensino de Ciências Naturais e Matemática - UFRN

Natal - RN

\section{Resumo}

Este artigo discorre sobre o conteúdo "Princípio de Arquimedes" nos livros didáticos de Física do PNLD 2018. Investiga-se, dentre outros aspectos históricos, a presença do episódio envolvendo Arquimedes (287 a.C. - 212 a.C.) e o problema da coroa do rei de Siracusa, recorrentemente propagado, sob um viés empirista-indutivista, como a "descoberta do empuxo". A proposta desenvolvida se descortina a partir de uma peculiaridade. Trabalhos acadêmicos em periódicos nacionais da área de Ensino de Física, nas últimas décadas, chamaram a atenção para aspectos histórico-filosóficos relacionados ao Princípio de Arquimedes. Pode-se questionar se essas discussões vêm tendo algum impacto nos livros didáticos. A análise crítica minuciosa mostra que ainda é frequente a presença da pseudo-história empirista-indutivista, bem como a apresentação historicamente descontextualizada do Princípio de Arquimedes. São também notáveis, nos livros analisados, repercussões dos questionamentos dos especialistas da área de Ensino de Física contra a narrativa mítica do episódio citado. Por vezes, notamse nesses livros referências explícitas aos trabalhos acadêmicos, mas a repercussão em iniciativas direcionadas ao professor e ao aluno é ainda embrionária. Por outro lado, dentre os doze livros didáticos analisados, há dois exemplos de transposição robusta da História da Ciência para o

\footnotetext{
${ }^{+}$The History of Science in PNLD 2018: Archimedes' Principle as a case study

* Recebido: 3 de agosto de 2020. Aceito: 14 de dezembro de 2020.

${ }^{1}$ E-mais: julianahidalgo@fisica.ufrn.br; daniel_dmq@ufrn.edu.br; mara_cristina@live.com
} 
contexto do ensino médio, explicitamente apoiados em trabalhos acadêmicos. Esses resultados apontam uma direção promissora.

Palavras-chave: Arquimedes; Pseudo-história; Livros didáticos.

\begin{abstract}
This paper discusses the content "Archimedes' Principle" in Physics textbooks from PNLD 2018. It is investigated, among other historical aspects, the presence of the episode which involves Archimedes (287 BC -212 BC) and the problem related to the crown of King Hieron II of Syracuse, repeatedly propagated, under an empiricist-inductivist perspective, as the "discovery of the buoyant force". The proposal is developed due to a peculiar circumstance. Academic works in national journals of the Physics Teaching field claimed attention, at last decades, to historical aspects related to Archimedes' Principle. One may wonder, then, whether their discussions have had any impact on textbooks. The meticulous and critical analysis shows yet frequent the presence of the empiricist-inductivist pseudo-history, in addition to the historically decontextualized presentation of Archimedes' Principle. Repercussions of disprovements, made by specialists in the Physics Teaching field against the aforementioned mythical narrative, are also notable in the analyzed textbooks. Sometimes, there are explicit references to the academic works, but their repercussion in initiatives aimed for teachers and for students is still embryonic in these textbooks. On the other hand, among the twelve analyzed, there are two textbooks with exemplary transposition of the History of Science into the context of high school, explicitly supported by academic works. These results point to a promising direction.
\end{abstract}

Keywords: Archimedes; Pseudo-history; Textbooks.

\title{
I. Introdução
}

É amplamente reconhecido na área de ensino de ciências o importante papel que a História e Filosofia da Ciência (HFC) desempenham na educação científica (MATTHEWS, 1995; MARTINS, 2006; DAMASIO; PEDUZZI, 2017). Não obstante as potencialidades, a inserção da HFC no ensino se configura como um desafio. Acevedo-Díaz e colaboradores afirmam que o interesse pelo ensino da "história da ciência [...] é crescente [...], apesar dos entraves que existem para sua introdução curricular" (2017, p. 141; tradução nossa). Uma das 
"barreiras" a serem transpostas é "a falta de material didático adequado (textos sobre história da ciência) que possa ser utilizado no ensino" (MARTINS, 2006, p. xxviii).

Faz-se necessário refletir sobre "a qual história da ciência se deve recorrer para se atingir os objetivos educacionais" (BALDINATO; PORTO, 2008, p. 1), tais como a compreensão da construção do conhecimento físico como um processo histórico (BRASIL, 2015a). De acordo com o referido objetivo, aponta-se a importância de "selecionar as versões históricas coerentes com os objetivos de sua prática pedagógica, ou discutir criticamente narrativas consideradas inadequadas" (FORATO; PIETROCOLA; MARTINS, 2011, p. 53).

É fundamental a atenção ao conteúdo histórico-filosófico exposto nos livros didáticos, uma vez que estes exercem um papel importante, sendo muitas vezes os únicos instrumentos de apoio ao professor, norteando sequências de conteúdos e atividades. Dado o seu protagonismo, o livro didático passa por um processo seletivo em face das normas regulamentadoras do PNLD (Programa Nacional do Livro Didático). O Edital do PNLD 2018 de Física traz indicadores avaliativos relacionados à História da Ciência:

\begin{abstract}
[...] utiliza abordagens do processo de construção das teorias físicas, [...] em consonância com vertentes epistemológicas contemporâneas; [...] apresenta expressões matemática de leis, sempre acompanhadas de seus enunciados próprios e em forma adequada, bem como da especificação de suas condiçães de produção ou criação; [...] apresenta os conteúdos conceituais da Física sempre acompanhados, ou partindo de sua necessária contextualização, [...] em relação aos seus contextos sóciocultural-histórico-econômicos de produção, [...] evitando a utilização de contextualizações artificiais para esses conteúdos (BRASIL, 2015b, p.
\end{abstract} 58)

$\mathrm{Na}$ literatura acadêmica, por sua vez, há recomendações acerca da elaboração de narrativas sobre episódios históricos para fins didáticos:

[...] faz-se uma seleção que simplifica em parte os feitos históricos [...], mas cuidando para que as omissões não conduzam a uma pseudo-história [...] e evitem, assim, uma imagem distorcida da ciência [...]. Igualmente, deve-se evitar mostrar uma visão mítica dos cientistas e da ciência [...] (ACEVEDO-DÍAZ; GARCÍACARMONA; ARAGÓN, 2017, p. 141; tradução nossa).

Apesar das recomendações legais e acadêmicas, notam-se comentários desanimadores acerca das lacunas em livros didáticos no tocante à História da Ciência:

[...] a história da ciência não está sendo apresentada da maneira sugerida pela nova historiografia da ciência. [...] a ciência é um empreendimento humano, coletivo, caracterizada por processos que preveem a contínua crítica ao próprio conhecimento científico estabelecido, e que interage com o meio social em que é produzida, então os livros didáticos precisam incorporar formas de se abordar a história da ciência [...] (VIDAL, 2009, p. 94). 
Enfatiza-se a importância de "identificar e lidar com a pseudo-história, quando presente em materiais didáticos", considerando a necessidade de "interagir de modo crítico com narrativas problemáticas da história das ciências" (FORATO, 2013, p. 1316). Silveira e Medeiros pontuaram: "Dentre tais mitos [...], boa parte está vinculada à mecânica dos fluidos e tem sido objeto de investigações" (2009, p. 275; grifo no original).

Nesse contexto, o presente trabalho analisa detalhadamente o conteúdo "Princípio de Arquimedes" nos livros didáticos aprovados no PNLD 2018. Investiga-se, dentre outros aspectos histórico-filosóficos, a presença de um caso de pseudo-história. Trata-se, especificamente, do episódio histórico envolvendo Arquimedes (287 a.C. - 212 a.C.) e o problema da coroa do Rei Hieron de Siracusa, recorrentemente propagado, sob um viés empirista-indutivista, como a "descoberta do empuxo".

A proposta desenvolvida se descortina a partir de uma situação peculiar. Em 1996, foi publicado na Revista Brasileira de História da Ciência o trabalho "Sobre os corpos flutuantes, tradução comentada de um texto de Arquimedes". Notas na tradução chamavam a atenção para duas narrativas sobre o episódio histórico supracitado, a do arquiteto romano Marcus Vitruvius Pollio, do século I a.C., e a de Galileu Galilei, do século XVII (ASSIS, 1996). No ano 2000, em edição do então Caderno Catarinense de Ensino de Física, hoje Caderno Brasileiro de Ensino de Física, o historiador da ciência Roberto Martins publicou o artigo "Arquimedes e a coroa do Rei: problemas históricos"2. Seu tema central foi o embate entre as duas narrativas, a de Vitruvius e a de Galileu. Como Martins demonstrou, a versão vitruviana, embora amplamente divulgada, pode ser questionada do ponto de vista histórico e é fisicamente inviável. O historiador descreveu como Galileu propôs uma narrativa mais plausível dos pontos de vista físico e histórico, corroborada por evidências históricas. Anos depois, em 2009, os pesquisadores Fernando Lang da Silveira e Alexandre Medeiros, no mesmo periódico, publicaram "O paradoxo hidrostático de Galileu e a Lei de Arquimedes". Eles afirmaram que "a Lei de Arquimedes tem sido um alvo preferencial de vários estudos educacionais [...]. [...] alguns têm dado especial atenção a certos aspectos da abordagem histórica que pode cercar a Lei de Arquimedes" (SILVEIRA; MEDEIROS, 2009, p. 3 ).

Esses são alguns exemplos de trabalhos em periódicos nacionais da área de Ensino de Física, de acesso aberto que, nas últimas décadas, chamaram a atenção para aspectos históricos relacionados ao Princípio de Arquimedes ${ }^{3}$. Pode-se questionar, então, se essas

\footnotetext{
${ }^{2}$ Foi reproduzido como capítulo de livro: MARTINS, R. A. Arquimedes e a coroa do rei: problemas históricos. In: STUDART, N.; OLIVIERI, C. A.; VEIT, E.; ZYLBERSZTAJN, A. (orgs.). Física - Ensino Médio. Coleção Explorando o Ensino, vol. 7. Brasília: MEC, 2005, p. 181-185. Um link a partir do site do Caderno Brasileiro de Ensino de Física mostra que o artigo de Martins está entre os 100 mais citados do periódico (https://scholar.google.com.br/citations?hl=pt-BR\&btnA=1\&user=J3_Bd00AAAAJ, acesso em 22 jul. 2020).

${ }^{3}$ O tratado La Bilancetta, de Galileu, aborda também o problema da coroa e foi traduzido para o vernáculo em 1986, sendo mais uma referência de acesso aberto online (GALILEI, 1986).
} 
discussões vêm tendo algum impacto nos livros didáticos. Como mostraremos, parece que sim, segundo evidencia a análise dos livros didáticos de Física aprovados no PNLD 2018. Há nesses livros, por exemplo, referências explícitas às publicações acadêmicas supracitadas. Dimensões positivas e negativas podem ser notadas nesse âmbito. Houve inciativas de incorporar aos livros didáticos elementos a partir dos referidos trabalhos acadêmicos. Algumas propostas foram bem conduzidas, outras não.

Na próxima seção, retomamos brevemente alguns aspectos abordados pelos trabalhos acadêmicos supracitados. Na seção subsequente, apresentamos uma análise detalhada do conteúdo "Princípio de Arquimedes" nos livros didáticos aprovados no PNLD 2018. Identificamos, dentre outros aspectos, eventuais referências anacrônicas e sincrônicas às conclusões de Arquimedes. Observamos a possível presença da pseudo-história amplamente associada ao episódio da coroa do rei. Buscamos verificar eventuais impactos de trabalhos acadêmicos acerca desse episódio. Adicionalmente, inspiramos nossa análise em critérios selecionados a partir de trabalho desenvolvido por Forato (2013). Na última seção, apresentamos considerações finais.

\section{O Princípio de Arquimedes e o episódio da coroa}

No tratado Sobre os Corpos Flutuantes encontramos a apresentação do próprio Arquimedes para o conhecimento, que atualizado, seria chamado "Princípio de Arquimedes":

Proposição 5 Qualquer sólido mais leve do que um fluido ficará, caso colocado no fluido, submerso de tal forma que o peso do sólido será igual ao peso do fluido deslocado. [...] Proposição $6 \mathrm{Se}$ um sólido mais leve do que um fluido for forçadamente submerso nele, o sólido será impelido para cima com uma força igual a diferença entre seu peso e o peso do fluido deslocado. Proposição 7 Um sólido mais pesado do que um fluido descerá, se colocado nele, ao fundo do fluido, e o sólido será, quando pesado no fluido, mais leve do que seu peso real pelo peso do fluido deslocado (ASSIS, 1996, p. 74-75).

A obra é uma construção intelectual descrita com geometria euclidiana, o que materializa a forte influência de Euclides no trabalho de Arquimedes. Evidências experimentais não estão presentes na argumentação. Igualmente não se nota, na construção de Arquimedes, a abordagem da força de empuxo com formulação matemática.

Como Arquimedes teria chegado a algumas de suas conclusões? O feito relacionado ao problema da coroa do Rei Hieron é amplamente conhecido. Na tradução de 1996 do tratado Sobre os Corpos Flutuantes para o vernáculo, são destacadas, em notas explicativas à Proposição 7, as duas versões para o episódio histórico, a vitruviana e a galileana. Reforça-se que a galileana é compatível com o conhecimento expresso por Arquimedes na referida proposição, bem como é corroborada por evidências históricas posteriores: 
[...] esta proposição pode seguramente ser considerada como decisiva na questão de como Arquimedes determinou as proporções de ouro e prata contidas na famosa coroa [...]. De fato a proposição sugere o seguinte método [segue-se a demonstração segundo versão galileana .... . Este procedimento corresponde bem de perto àquele descrito no poema de ponderibus et mensuris (escrito provavelmente ao redor de 500 d.C.) com o objetivo de explicar o método de Arquimedes (ASSIS, 1996, p. 76-77).

Avaliação semelhante é reforçada por Martins (2000). O historiador lembra que Galileu, em referência às proposições do Sobre os Corpos Flutuantes, argumentou que sua narrativa para o método empregado por Arquimedes para resolver o problema da coroa se apoiava em demonstrações realizadas pelo próprio pensador grego. Não há documentos da época do próprio Arquimedes que descrevam esse método e o atribuam a ele. No entanto, uma evidência documental reforça que a interpretação de Galileu para o episódio estava correta. O poema Carmen de ponderibus et mensuris, datado do século IV ou V d.C., relata o método da balança hidrostática e o atribui explicitamente a Arquimedes.

Mas, afinal, no que consistiriam essas duas narrativas? A narrativa vitruviana, fantasiosa e mundialmente conhecida, diz-nos:

Quando Hieron soube, através de uma denúncia, que certa quantidade de ouro havia sido retirada e substituida pelo equivalente em prata, incorporada ao objeto votivo, furioso por haver sido enganado, mas não encontrando nenhum modo de evidenciar a fraude, pediu a Arquimedes que refletisse sobre isso. E o acaso fez com que ele fosse se banhar com essa preocupação em mente e ao descer à banheira, notou que, à medida que lá entrava, escorria para fora uma quantidade de água igual ao volume de seu corpo. Isso lhe revelou o modo de resolver o problema: sem demora, ele saltou cheio de alegria para fora da banheira e completamente nu, tomou o caminho de sua casa, manifestando em voz alta para todos [...] (VITRUVIUS, De l'architecture apud MARTINS, 2000, p. 117).

A fonte dessa versão teria sido Marcus Vitruvius, no século I a.C., dois séculos após a ocorrência do referido episódio. Em De architectura, ele descreveu o procedimento supostamente executado por Arquimedes. Questionamentos de naturezas diversas levantam suspeitas a respeito dessa versão (MARTINS, 2000). Argumenta-se que Vitruvius não é uma fonte fidedigna por não ser contemporâneo de Arquimedes. Um segundo ponto levantado é que, à época de Arquimedes, um escravo preparava o banho do senhorio, e, sendo assim, não haveria razão para encher a banheira até a borda se ele teria que secar o chão depois.

Argumentos apoiados em conhecimentos físicos contrariam a narrativa. A técnica supostamente atribuída a Arquimedes desconsidera a tensão superficial da água. Há outro argumento de cunho físico. De acordo com esse método, Arquimedes teria medido o volume do líquido deslocado pela submersão da coroa na água. Portanto, ele teria medido o quanto subia o nível da água. Supondo uma coroa de ouro de $1000 \mathrm{~g}$, e considerando $19,28 \mathrm{~g} / \mathrm{cm}^{3}$ a 
densidade do ouro, teríamos que seu volume seria cerca de $52 \mathrm{~cm}^{3}$. Para uma coroa com 20 $\mathrm{cm}$ de diâmetro, precisaríamos de um recipiente circular de área mínima de $314 \mathrm{~cm}^{2}$. A subida do nível do líquido seria de cerca de $0,16 \mathrm{~cm}$. Consideremos, por outro lado, que o artesão tivesse, de fato, enganado o rei. A densidade da prata é $10,5 \mathrm{~g} / \mathrm{cm}^{3}$. Repetiremos os cálculos para uma liga de ouro e prata, considerando a densidade de $14,89 \mathrm{~g} / \mathrm{cm}^{3}$, uma média entre os dois metais. Teremos um valor de $0,21 \mathrm{~cm}$ para a elevação do nível. Considerando valores da ordem de 1 a 2 mm, não era possível fazer as medições com os recursos então disponíveis.

Esse tipo de análise não é atual. Galileu Galilei, em La Bilancetta afirmou que o método citado por Vitruvius "era todo falho, faltando-lhe a precisão requerida nas coisas matemáticas" (GALILEI, 1986, p. 105). Galileu buscou em obras de Arquimedes argumentos que explicassem como ele pôde "descobrir, por meio da água e de modo rigoroso, a composição da liga de dois metais" (GALILEI, 1986, p. 105). Expôs, então:

[...] a bola de ouro pesa na água tanto quanto o peso do ouro excede o peso da água. [...] E tendo os metais diferentes pesos (especificos), os seus pesos na água diminuirão em diferentes proporções (GALILEI, 1986, p. 106).

Em termos atuais, dizemos que o conceito físico envolvido na resolução do problema da coroa é o empuxo. Esse tipo de ideia está nos dizeres de Galileu Galilei transcritos anteriormente e resumem o que o pensador encontrou ao estudar Arquimedes. Com base nessa concepção, Galileu explicou que o raciocínio de Arquimedes teria como base uma "balança hidrostática". Considerou uma balança em equilíbrio no ar, tendo uma porção de metal em um braço e um peso equivalente no outro. Quando o metal era submergido em água, havia um desequilíbrio. A ideia era que objetos com a mesma massa e densidades diferentes, teriam volumes maiores quanto menor fosse a densidade. $\mathrm{O}$ objeto de maior volume, quando imerso em água, sofreria um empuxo maior e, então, teria um peso aparente menor.

Essa outra versão é fisicamente consistente. No entanto, sabemos como são atrativas as narrativas de descobertas científicas que recebem incrementos espetaculosos com o intuito de promoverem seus personagens. A narrativa vitruviana sobre a descoberta repentina do empuxo é um exemplo de mito amplamente divulgado, tomado como relato verídico. Ao entrar em uma banheira, em um insight repentino, Arquimedes, a partir da observação do transbordamento da água, descobre a solução para o problema. A demonstração, uma vez realizada, é evidente, óbvia. São destacadas, ainda, idiossincrasias geralmente atribuídas a pesquisadores/cientistas. Arquimedes não se preocupa com a higiene pessoal e com a aparência física. Tem um comportamento social exótico, ao sair nu, correndo pelas ruas.

Narrativas desse tipo costumam ser inseridas em aulas por professores que as consideram motivadoras e engraçadas. No entanto, elas contribuem para a propagação de visões simplistas sobre a ciência (GIL-PÉREZ et al., 2000). Transmitem uma concepção individualista de ciência, ao associarem tais descobertas a indivíduos únicos. Transmitem uma 
visão empirista-indutivista de ciência, uma vez que narram descobertas instantâneas a partir de observações simples, desconsiderando contextos teóricos.

Pesquisadores do ensino de Física, dedicados à inserção didática da HFC, Silveira e Medeiros identificaram a presença de concepções empiristas-indutivistas no ensino do Princípio de Arquimedes. Narrativas experimentais à moda vitruviana são "a principal peça de convencimento oferecida pelos livros didáticos" (SILVEIRA; MEDEIROS, 2009, p. 276): um corpo colocado para flutuar em um vaso repleto de água faz extravasar uma quantidade de líquido, que, se pesada, é equivalente ao peso do corpo colocado a flutuar.

No artigo "O paradoxo hidrostático de Galileu e a Lei de Arquimedes", Silveira e Medeiros se opõem justamente a esse tipo de narrativa tão frequente no ensino tradicional de Física: "As abordagens das condições de flutuação aqui apresentadas tentam romper esse discurso ideológico tradicional, repleto de lacunas, calcado em pressupostos empiristasindutivistas" (2009, p. 290). Os autores se opõem à forma como a Lei de Arquimedes é apresentada nos livros didáticos, e fazem referência a críticas apresentadas ainda no século XVII a esse tipo de enunciado:

[...] a Lei de Arquimedes, da forma como costuma ser apresentada "experimentalmente" nos livros-texto, nos induz fatalmente a um erro de avaliação. A referida lei afirma que: "todo corpo mergulhado em um líquido sofre um empuxo de baixo para cima igual ao peso do fluido por ele deslocado". A principal peça de convencimento educacional comumente oferecida pelos livros didáticos de Física para que o aprendiz aceite a validade de tal afirmativa de Arquimedes é um "experimento" no qual um corpo é inicialmente colocado a flutuar em um vaso já repleto de água. No referido "experimento" - usualmente ilustrado nos livros toda a água que extravasa do recipiente é recolhida e convenientemente pesada. $O$ resultado mostra que o peso desta água deslocada é igual ao peso do corpo colocado a flutuar. O tal experimento parece convincente, a julgar pelo uso secular que os autores de livros didáticos de Física têm feito do mesmo [...]. [...] tal experimento tem sido assumido como uma peça de evidência válida, convincente e insofismável da referida Lei de Arquimedes, sem que se leve em conta que a justeza desse argumento já houvesse sido criticada no século XVII por Galileu [...] (SILVEIRA; MEDEIROS, 2009, p. 276).

Os autores demonstram, com base em um experimento paradoxal elaborado e realizado por Galileu, que o enunciado tradicional da Lei de Arquimedes está equivocado e precisaria ser alterado:

Evidencia-se um erro na formulação usual da Lei de Arquimedes no Paradoxo Hidrostático de Galileu, pois um corpo pode flutuar em um fluido mesmo quando o peso de todo o fluido disponivel é menor do que o peso do corpo. Para que a Lei de Arquimedes evite, não propicie o Paradoxo Hidrostático de Galileu, deve ser formulada do seguinte modo: todo corpo mergulhado em um líquido sofre um empuxo de baixo para cima igual ao peso do fluido contido em um volume idêntico 
Como se pode notar pela presente seção, trabalhos acadêmicos em periódicos de destaque, e acessíveis a autores de livros didáticos, vêm há algum tempo dando atenção ao Princípio de Arquimedes e apontando repercussões importantes para o ensino desse conteúdo físico e sua abordagem histórica. Afirma-se ser recomendável que se traga para o contexto escolar uma narrativa mais plausível dos pontos de vista físico e histórico, que não transpareça concepções ingênuas sobre a ciência, pois a narrativa vitruviana:

Dá a impressão de que a ciência evolui por acidentes [...]. Além de proporcionar uma visão histórica falsa, essa versão popular faz um serviço negativo ao próprio ensino da física, pois descreve um método inviável de comparação de densidades, em vez de ensinar como se poderia realmente detectar a fraude (MARTINS, 2000, p. 121).

Essas discussões têm tido algum impacto nos livros didáticos? Em princípio deveriam ter, se considerarmos que na avaliação realizada pelo PNLD: "A atualização dos conteúdos e procedimentos mobilizados pela obra constitui em um dos principais critérios para a análise do livro [...]” (SCHIVANI; SOUZA; LIRA, 2020, p. e20200011-3).

\section{Análise dos livros didáticos}

Na edição do Programa Nacional do Livro Didático, em 2018, foram aprovadas 12 coleções de Física (vide Referências). Em particular, no primeiro volume dessas coleções, figura o conteúdo relacionado ao "Princípio de Arquimedes". Analisamos detalhadamente a presença desse conteúdo em cada um desses exemplares (versão do aluno e manual para o professor). Dentre outros aspectos, observamos possíveis anacronismos nas conclusões atribuídas ao pensador. Investigamos a eventual presença da pseudo-história associada à "descoberta do empuxo". Buscamos identificar impactos de discussões acadêmicas sobre o referido episódio histórico. Adicionalmente, inspiramo-nos também em uma seleta a partir de "um conjunto de indicativos para identificação e problematização da pseudo-história" sintetizado no trabalho de Forato (2013, p. 1317): concepções empírico-indutivistas, episódios protagonizados por insights individuais de grandes gênios, visões simplistas sobre a ciência.

\section{Física: Contexto \& Aplicações, de Luz, Álvares e Guimarães}

Nessa obra didática, na seção "Física no contexto", "O problema de Arquimedes" intitula um texto contendo como real uma narrativa aproximada da versão vitruviana. $\mathrm{O}$ texto 
é iniciado com pontual anacronismo - Arquimedes é dito cientista ${ }^{4}$. A citação a seguir narra a solução repentina do problema da coroa do rei:

[...] Arquimedes foi encarregado pelo rei de investigar se essa acusação era, de fato, verdadeira. Conta-se que, ao tomar banho em um banheiro público, observando a elevação da água à medida que mergulhava seu corpo, Arquimedes percebeu que poderia resolver o problema. Entusiasmado, saiu correndo para casa, atravessando as ruas completamente despido e gritando a palavra grega que se tornou famosa: Heureka! Heureka! (isto é: “Achei! Achei!”) (LUZ; ÁLVARES; GUIMARÃES, 2016, p. 239).

A citação dá a entender que Arquimedes pôde medir a elevação da água, a qual demonstramos ser diminuta. Afirma-se ter havido uma observação da elevação da água, apenas. No livro didático, há uma figura ao lado do trecho narrativo: a banheira não está cheia, longe da iminência de extravasamento. Muito além, e em contraste, Vitruvius escreveu que Arquimedes descia à banheira e notou que "à medida que lá entrava, escorria para fora uma quantidade de água igual ao volume de seu corpo" (apud MARTINS, 2000, p. 117). Quem encheria uma banheira a ponto de transbordar ao adentrá-la? Tal questionamento, interessante para a crítica documental, perde existência diante dessa primeira passagem do texto didático que adota uma pseudo-história infiel à narrativa vitruviana original.

Na continuidade, Luz, Álvares e Guimarães passam a se referir ao extravasamento da água. Afirmam a realidade da versão vitruviana. Uma sequência operacional, passo a passo, resulta no conhecimento científico:

E realmente Arquimedes conseguiu resolver o problema da seguinte maneira: $1^{\circ}$ ) Mergulhou em um recipiente completamente cheio de água uma massa de ouro puro, igual à massa da coroa, e recolheu a água que transbordou [...]. 2º Retomando o recipiente cheio de água, mergulhou nele uma massa de prata pura, também igual à massa da coroa, recolhendo a água que transbordou. Como a densidade da prata é menor que a do ouro, o volume de água recolhido, nessa segunda operação, era maior do que na primeira [...]. $3^{\circ}$ ) Finalmente, mergulhando no recipiente cheio de água a coroa em questão, constatou que o volume de água recolhido tinha um valor intermediário entre aqueles recolhidos na primeira e na segunda operações [...]. Ficou, assim, evidenciado que a coroa não era realmente de ouro puro [...] (LUZ; ÁLVARES; GUIMARÃES, 2016, p. 239).

O transbordamento, antes excluído, faz-se necessário em cada uma das três “operações" supostamente conduzidas por Arquimedes. No exemplar, uma dúzia de páginas posteriores, afirma-se a descoberta do empuxo como decorrente de investigações empíricas:

\footnotetext{
${ }^{4} \mathrm{O}$ termo "cientista" começou a designar os que se dedicavam profissionalmente à ciência apenas a partir do século XIX, após ter sido cunhado, em 1833, pelo estudioso inglês William Whewell (1794-1866). Antes disso, usavam-se as referências "filósofo natural" e "homem da ciência".
} 
[...] Arquimedes, realizando experiências cuidadosas, descobriu uma maneira de calcular o empuxo que atua em objetos mergulhados em líquidos. Suas conclusões foram expressas por intermédio de um princípio, denominado Princípio de Arquimedes, cujo enunciado é o seguinte: "Todo objeto mergulhado em um líquido 5 recebe um empuxo vertical, para cima, igual ao peso do líquido deslocado pelo objeto" [...]. Usando as leis de Newton, poderíamos chegar a esse mesmo resultado para o cálculo do empuxo. Perceba, entretanto, que Arquimedes descobriu esses fatos por meio de experiências, muitos anos antes de Newton estabelecer as leis básicas da Mecânica (LUZ; ÁLVARES; GUIMARÃES, 2016, p. 253).

É louvável que explicitem a existência de Arquimedes "muitos anos antes de Newton" (na verdade, cerca de dois milênios). Destaca-se, ainda, que a expressão "realizando experiências cuidadosas" exprime a ideia de esforço e dedicação ao trabalho empírico, em contraste com o simples insight assinalado na narrativa vitruviana (citada pelo mesmo exemplar!?). Essa referência poderia ser positiva, por caracterizar o esforço na atividade científica. Por outro lado, diz-se que "Arquimedes descobriu esses fatos por meio de experiências" e não são explicitados elementos teóricos, como demonstrações geométricas na argumentação do pesquisador. A redação pode induzir à compreensão empirista-indutivista ${ }^{6}$ de descoberta pelo experimento. É conveniente lembrarmos, ainda, que Arquimedes não se apoiou em evidências experimentais em Sobre os corpos flutuantes (ASSIS, 1996).

Há de se destacar, ainda, certo anacronismo e individualismo na conclusão explicitamente atribuída a Arquimedes. A redação atualizada do Princípio e o termo empuxo são notados. O empuxo é uma grandeza vetorial cuja proposição foi humana e coletivamente construída ao longo do tempo, não se devendo exclusivamente às contribuições de Arquimedes. O conceito de fluido igualmente deriva de uma construção coletiva.

\section{Física para o Ensino Médio, de Yamamoto e Fuke}

Inicialmente, os autores questionam o leitor sobre o que provoca a diminuição aparente do peso de um corpo na piscina. É feliz apontarem como resposta "um princípio físico estudado desde os tempos da Grécia antiga, hoje denominado Princípio de Arquimedes" (YAMAMOTO; FUKE, 2016, p. 277). Referem-se, assim, ao fato de que o conhecimento sobre o fenômeno remonta a épocas distantes, ao mesmo tempo em que localizam a atualidade da nomenclatura "Princípio de Arquimedes". Prosseguem com a afirmação:

Naquela época, Arquimedes chegou à conclusão de que todo corpo imerso total ou parcialmente em um fluido em equilíbrio acaba sofrendo uma força, aplicada por

\footnotetext{
${ }^{5} \mathrm{O}$ enunciado restringe a força a fluidos líquidos. Mas, após duas páginas, em uma incoerência interna ao texto didático, Luz, Álvares e Guimarães recorrem à subida de um balão na atmosfera.

${ }^{6}$ Em artigo sobre o Princípio, Silveira e Medeiros apontam: "O ensino tradicional da Física tem padecido, dentre outros problemas, de uma exagerada tendência indutivista ingênua [...], vincular a geração de ideias e teorias às observações empíricas, de uma forma direta e praticamente sem qualquer intermediação teórica" (2009, p. 274).
} 
este, com direção vertical, sentido voltado para cima e módulo igual ao peso da parte fluida deslocada. A essa força deu-se o nome de empuxo (YAMAMOTO; FUKE, 2016, p. 277; grifo no original).

O trecho, anacrônico e imbuído de uma visão individualista de ciência, atribui ao próprio Arquimedes uma conceituação na qual aparecem componentes de uma entidade vetorial e a visão atual de fluido, em muito se afastando das conclusões do estudioso.

Yamamoto e Fuke apresentam a pseudo-história vitruviana. Na seção "Arquimedes, o empuxo e o significado da palavra Eureka", assim introduzem uma História em Quadrinhos (HQ) do cartunista britânico Kevin Kallaugher: "Grandes acontecimentos do passado chegam até nós por meio da palavra escrita, pela tradição oral e pelo registro em imagens. Eles são recontados, com alterações ou exageros, e seus personagens acabam por ser imortalizados" (YAMAMOTO; FUKE, 2016, p. 279). A ressalva é, no entanto, insuficiente. Os exageros e as alterações, nesse caso, resultam em uma narrativa inadequada do ponto de vista físico e histórico, embebida em visões simplistas sobre a ciência.

A HQ traz a versão vitruviana, por si exagerada, com mais exageros: Arquimedes parece pular e não meramente adentrar uma banheira que transborda - "Tchibum!" - e há a personificação de um pato, acompanhante do pensador nos quadrinhos. A comparação com a HQ original, em inglês, demonstra que, na versão em vernáculo apresentada no exemplar didático, o sexto quadrinho não foi traduzido adequadamente. No original, o pato personificado - estando molhado devido ao transbordamento da água - afirma: "He could use a little less volume..." [Ele (Arquimedes) poderia usar um pouco menos de volume (de água na banheira, para evitar o transbordamento)]. Por sua vez, Yamamoto e Fuke traduzem assim a fala: "Ele bem que poderia ter volume um pouco menor..." (2016, p. 279).

O cartunista britânico corrobora a versão vitruviana, mas aponta - o que Yamamoto e Fuke negligenciaram - a um elemento questionável na narrativa, como Martins registrou:

Por que motivo alguém encheria uma banheira até a borda? Para molhar todo o chão do lugar onde a pessoa ia tomar banho? Se o banho havia sido preparado por um escravo (uma hipótese plausivel), ele próprio teria que secar todo o chão, depois. Não é muito razoável [...] (MARTINS, 2000, p. 118).

No exemplar do aluno, a HQ é usada estritamente como motivação para uma atividade simples de manipulação matemática e outra referente à densidade de materiais. Os autores nem ao menos chamam a atenção do professor para quais seriam os equívocos na narrativa (os exageros e alterações que reconhecem existir), suas repercussões e a consequente necessidade de intervenção. Estariam transferindo ao professor qualquer iniciativa em relação a problematizar esses aspectos e, eventualmente, apresentar uma narrativa fisicamente viável e adequada do ponto de vista histórico? O procedimento adotado por Yamamoto e Fuke ratifica a pseudo-história.

A versão do professor do exemplar traz um único apontamento específico, mas este 
se refere a outro contexto e se localiza lateralmente ao trecho que expõe o enunciado do Princípio. Nessa versão, em nota destacada, aparece uma referência a um texto acadêmico, seguida do link de acesso a este: "O Caderno Brasileiro de Ensino de Física, vol. 26, n. 2, 2009, traz uma atualização do Princípio de Arquimedes, sugerindo uma nova formulação para que se escape do paradoxo hidrostático de Galileu. O texto se encontra disponível em [...]" (YAMAMOTO; FUKE, 2016, p. 277).

Mas, o que seria o "paradoxo hidrostático"? Ao professor, sequer é mencionado na referida nota o título do trabalho em questão. O link leva ao artigo "O paradoxo hidrostático de Galileu e a Lei de Arquimedes" de Fernando Lang da Silveira e Alexandre de Medeiros. Como citamos na seção anterior, curiosamente, ao longo do referido artigo, Silveira e Medeiros se opõem justamente ao tipo de narrativa de cunho empirista-indutivista encontrada na HQ apresentada no exemplar de Yamamoto e Fuke.

A referência ao trabalho de Silveira e Medeiros indica que os autores do livro didático conhecem a discussão galileana sobre a balança hidrostática, e estão cientes das críticas às narrativas empiristas-indutivistas relacionadas ao empuxo. No entanto, a HQ apresentada no livro didático é exemplo emblemático de um episódio que se descortina a partir de um "discurso ideológico tradicional, repleto de lacunas, calcado em pressupostos empiristas-indutivistas" (SILVEIRA; MEDEIROS, 2009, p. 290). Ou seja, mesmo dispondo de fonte acadêmica qualificada, Yamamoto e Fuke não fizeram, eles próprios, bom uso desse recurso. Transferiram o encargo ao professor, a quem dirigiram uma nota curta, hermética, que não chama a atenção para a importância da discussão.

O apontamento não permite que o professor se dê conta da relevância do conteúdo apresentado no link e do seu contraste em relação ao conteúdo do livro, o que se depreende de admoestações contidas no artigo acadêmico. Silveira e Medeiros, como mostramos na seção II, questionam o próprio enunciado tradicional do Princípio de Arquimedes, o qual consideram equivocado. Propõem uma modificação substancial nesse enunciado ao evidenciarem um erro na formulação usual desse Princípio. Com a nota isolada, Yamamoto e Fuke parecem remeter ao professor a correção do enunciado do Princípio de Arquimedes apresentado no próprio livro didático. Vale questionar, ainda, se o professor, mesmo que se atentasse para a evasiva nota auxiliar do material didático, conseguiria fazer uso do texto acadêmico para desenvolver, ele próprio, uma inserção didática para os conhecimentos advindos daquele material ${ }^{7}$.

\footnotetext{
${ }^{7}$ Para reflexão, citaremos uma ocorrência que pode sinalizar que, para o professor, a leitura e a inserção didática do conteúdo histórico-filosófico a partir de textos acadêmicos não seriam triviais. Forato (2013), ao realizar uma atividade de formação docente para a identificação de pseudo-história em materiais didáticos, propôs como um dos textos de leitura para um grupo de licenciandos em Física, o artigo de Martins (2000). Em face das dificuldades iniciais na compreensão, os textos precisaram ser disponibilizados com o acompanhamento de questões abertas.
} 


\section{Física: Interação e Tecnologia, de Gonçalves Filho e Toscano}

Sem abordagem histórica, o princípio de Arquimedes é apresentado em seu enunciado atual. A única referência histórica encontrada é uma pintura de um homem pensativo, que olha para uma folha de papel (GONÇALVES FILHO; TOSCANO, 2016, p. 141). A imagem, escura, pouco nítida, sem fonte ou autoria registrada, está acompanhada pela legenda "Retrato de Arquimedes (287 a.C. - 212 a.C.)". A figura apresentada é a imagem disponível na Wikipedia para o verbete Arquimedes ${ }^{8}$. Trata-se da pintura a óleo realizada por Domenico Fetti em 1620, a qual traz o sábio grego em trajes compatíveis com o século XVII.

A flutuação dos corpos é o cerne da seção "Princípio de Arquimedes": "De acordo com o princípio de Arquimedes, ao mergulharmos um corpo num fluido, o módulo da força de empuxo vai aumentando à medida que o objeto imerge" (GONÇALVES FILHO; TOSCANO, 2016, p. 141). O fenômeno em si foi, com efeito, tratado por Arquimedes no tratado Sobre os corpos flutuantes, mas o arcabouço geométrico da fonte primária perde lugar para a matematização do paradigma científico moderno, de acordo com o qual o princípio é exposto. Dada a ausência de considerações históricas, o enunciado contemporâneo e as expressões matemáticas associadas podem parecer construções individuais do pensador grego.

\section{Compreendendo a Física, de Gaspar}

Segue o mesmo padrão do exemplar anterior. Traz o conceito de empuxo de forma direta e descontextualizada historicamente. Prioriza o formalismo matemático. Não traz a pseudo-história vitruviana sobre a descoberta do empuxo. Por outro lado, exime-se de qualquer referência histórica qualificada. A lacuna em termos de contextualização histórica caracteriza a visão de ciência a-histórica (GIL-PÉREZ et al., 2001), e pode transmitir a impressão anacrônica de que o enunciado a seguir, contemplando os conceitos atuais de empuxo e de fluido, foi escrito por Arquimedes:

O empuxo é uma força com módulo, direção e sentido definidos pelo princípio de Arquimedes (filósofo e matemático grego que viveu de 287 a.C. a 212 a.C.): Todo corpo imerso num fluido sofre a ação de uma força - chamada de empuxo dirigida verticalmente para cima, cujo módulo é igual ao módulo do peso do volume do fluido deslocado (GASPAR, 2016, p. 267).

O exemplar destaca que "o princípio de Arquimedes, a rigor, não é um princípio, pois pode ser deduzido a partir da lei de Stevin" (GASPAR, 2016, p. 267). Na ausência de uma contextualização histórica adequada, pode-se ter a impressão de que este foi o caminho seguido por Arquimedes na elaboração do referido conhecimento, muito embora Simon Stevin (1548-1620) tenha desenvolvido seus estudos dezoito séculos depois.

\footnotetext{
${ }^{8}$ Disponível em: <https://pt.wikipedia.org/wiki/Arquimedes>. Acesso em: 29 abr. 2020.
} 


\section{Ser Protagonista - Física, de Fukui, Molina e Venê}

Em relação ao Princípio de Arquimedes, as referências históricas são reduzidas a poucos comentários: "O pensador grego Arquimedes (c. 287 a.C. - 212 a.C.) foi quem primeiro observou e apresentou essa força. Em linguagem atual, o princípio de Arquimedes diz [...]" (FUKUI, MOLINA, VENÊ, 2016, p. 245). O tom da afirmação remete à busca de precursores típica da historiografia Pedigree das primeiras décadas do século XX, que buscava registrar os "pais" de descobertas científicas (ALFONSO-GOLDFARB, 1994). A expressão "em linguagem atual" desfaz o anacronismo presente na atribuição da redação atual do princípio a Arquimedes, equívoco notado em outros exemplares. Por outro lado, não ficam claras quais as atualizações desse enunciado e o que foi pensado no século III a.C.

Em viés empirista-indutivista, pressupondo um conhecimento que emerge de experimentos, prossegue-se à demonstração da equação do empuxo: "Experimentos mostram que o volume de fluido deslocado [...] pela imersão de um corpo tem peso equivalente à força que será aplicada ao corpo" (FUKUI, MOLINA, VENÊ, 2016, p. 245). Chama-nos atenção o exercício resolvido do tópico:

Duas coroas idênticas são penduradas cada uma em um dinamômetro [...]. Uma delas está imersa em água, e a outra no ar. A massa de ambas as coroas é igual a $0,4 \mathrm{~kg}$, e o material de que são feitas é a prata, cuja densidade é $10500 \mathrm{~kg} / \mathrm{m}^{3}$ [...] a) Os valores marcados em cada dinamômetro [...] são diferentes. Explique por que ocorre essa diferença. b) Calcule o volume de cada uma das coroas. c) Calcule o empuxo que atua sobre a coroa imersa na água. d) Calcule o peso aparente. e) Interprete, do ponto de vista da Física, o significado da expressão "peso aparente", (FUKUI; MOLINA; VENÊ, 2016, p. 246).

Não há abordagem histórica. Apesar disso, a história sobre Arquimedes e a coroa do rei repercute no exercício resolvido, sem qualquer adoção entre as versões históricas. Menciona-se a versão vitruviana e questiona-se de passagem a sua veracidade somente na descrição de uma leitura indicada pelos autores:

A história de Arquimedes saltando de sua banheira e gritando "Eureca!'” é bastante conhecida (será verdadeira?). Pouca gente, porém, sabe que o grego alardeou que era capaz de mover o mundo. Pode-se saber dessa e de outras histórias lendo o livro Arquimedes e a alavanca em 90 minutos (FUKUI; MOLINA; VENÊ, 2016, p. 260).

A indagação é realizada em vão, a menos que o professor considere o questionamento relevante e se encarregue de mediar uma problematização a respeito. Mas, para isso, não conta com qualquer tipo de apoio na versão do professor desse exemplar. A abordagem histórica não parece ser prioridade. 


\section{Física-Ciência e Tecnologia, de Torres e colaboradores}

O exemplar apresenta uma imagem da obra Retrato de Arquimedes, devidamente referenciada a Giuseppe Nogari, pintor do século XVIII. A caixa "Biografia" é descrita como: "História da vida de cientistas ligados ao assunto tratado no capítulo em questão e suas contribuições ao avanço da Ciência" (TORRES et al., 2016, p. 6). Após a conceituação de fluido, o nome Arquimedes aparece realçado - identificando-o como "cientista" - e com sua biografia apresentada logo abaixo. Inicialmente, o recorte biográfico afirma que Arquimedes exerceu seis ofícios: "filósofo, matemático, físico, engenheiro, inventor e astrônomo" TORRES et al., 2016, p. 131). Menciona-se que ele foi contemporâneo de Eratóstenes e teve sua formação intelectual "em Alexandria, onde teria conhecido e mergulhado fundo na Geometria de Euclides" (TORRES et al., 2016, p. 131). Há interesses e realizações e, eventualmente, influências recebidas pelo pesquisador. Apresenta-se, em exaltação de natureza biográfica heroica, feitos do "principal matemático da Antiguidade". Fatores humanos não são reforçados no recorte biográfico, mas sim em indicações de leitura no final do capítulo ${ }^{9}$. Na finalização da biografia, uma nota tende a se contrapor a uma percepção anacrônica: "Talvez seu trabalho mais célebre seja o estudo da flutuação dos corpos, hoje conhecido como princípio de Arquimedes, introduzindo o conceito de empuxo" (TORRES et al., 2016, p. 131). Desse modo, não há a afirmação de que a nomenclatura atual esteja no trabalho original de Arquimedes, ao passo que a introdução do conceito sim.

No capítulo sobre hidrostática, os autores apresentam "O que diz a história Arquimedes", uma abordagem histórica, efetiva, de cerca de duas páginas. Afirmam a importância de suas habilidades práticas e teóricas. Assumem por verdadeira a ocorrência do episódio sobre a coroa do rei. Contudo, expressam ressalva quanto à narrativa dos fatos: "Embora muitos desses relatos careçam de uma análise mais cuidadosa sobre o desenrolar dos fatos envolvidos, não se questiona sua veracidade, mas sim o modo como realmente ocorreram" (TORRES et al., 2016, p. 131). Ensaiam a apresentação do relato vitruviano e da hipótese galileana, aos moldes de Martins (2000). Sobre a versão de Vitruvius, escrevem:

Um desses relatos, talvez o mais conhecido, atribuído ao arquiteto romano Vitrúvio (século I a.C.) [...] [Arquimedes] começou a pensar num modo de esclarecer a questão, sem ter de desfazer a coroa para analisar sua verdadeira composição. Conta-se que, durante um banho, observando o transbordamento da água ao entrar na banheira, ele teve a inspiração [...]. Entusiasmado com a descoberta, teria saído pelas ruas de Siracusa gritando Eureka! Eureka!, palavra que em grego significa "achei" ou "descobri". Segundo Vitrúvio, Arquimedes mergulhou completamente em água, em etapas sucessivas, um bloco de prata e um de ouro, ambos com massas iguais à da coroa, e a própria coroa. Depois de medir e comparar os volumes de água derramados pelos três corpos, ele constatou que o volume derramado pela

\footnotetext{
${ }^{9}$ Nota-se que as indicações de leitura objetivam destacar aspectos humanos e sociais, como "os principais feitos científicos de Arquimedes e suas implicações para a sociedade da época" e "a personalidade e a mente de Arquimedes" (TORRES et al., 2016, p. 163).
} 
coroa tinha um valor diferente do volume de água derramado pelo bloco de ouro. Ficava assim provada a fraude [...] (TORRES et al., 2016, p. 132).

A versão de Vitruvius foi amenizada. A caricatura de Arquimedes é menos excêntrica do que na fonte primária. Não traz o pensador correndo alegremente nu. À narrativa, o exemplar didático contrapõe de imediato a descrição de Galileu e os questionamentos deste à versão vitruviana:

Galileu Galilei (1564-1642) escreveu um pequeno tratado, intitulado La Bilancetta [...] no qual descreveu detalhadamente [...] a balança hidrostática, para determinar com grande precisão a densidade dos corpos ou sua composição, no caso de uma mistura. [...] Galileu questionou a versão de Vitrúvio sobre o método usado por Arquimedes [...]. De acordo com Galileu, o método do transbordamento exigiria um altíssimo grau de precisão nas medidas dos volumes de água deslocados, algo bastante improvável na época de Arquimedes. A balancinha de Galileu utiliza os princípios da alavanca e da flutuação, de autoria do próprio Arquimedes. Com esse instrumento, e aplicando o conceito de empuxo, Arquimedes poderia medir o "peso aparente" da coroa e dos blocos de ouro e prata, quando mergulhados em água, $e$ compará-los. Em seu tratado, Galileu afirma que esse teria sido o método mais apropriado para as condições experimentais da época de Arquimedes (TORRES et al., 2016, p. 132).

É feliz a explicitação da existência de um relato histórico mais plausível. É também muito feliz os autores considerarem os instrumentos de medidas de modo diacrônico, afirmando a impossibilidade de haver o grau de precisão necessário para Arquimedes medir os volumes que o relato de Vitruvius requereria. Por outro lado, pode induzir a uma interpretação anacrônica mencionar Arquimedes "aplicando o conceito de empuxo", cuja construção intelectual é introdutória e descrita com geometria euclidiana em seu tratado, diferindo-se da abordagem atual da força de empuxo, com formulação matemática.

Considerando que o método adotado por Arquimedes [...] tenha sido semelhante ao proposto por Galileu em La Bilancetta [...] tomando-se uma porção de ouro puro e a coroa, de massas iguais, e pendurando-as cada uma em uma das extremidades de uma barra reta, esta ficaria equilibrada na horizontal [...]. Se a coroa fosse de ouro puro, seu volume seria igual ao volume do bloco de ouro, preso na outra extremidade e, quando o sistema fosse mergulhado em água, ambos os corpos deslocariam volumes iguais do líquido, não alterando assim a posição de equilibrio da barra. No entanto, não foi isso o relatado. Dentro da água, a coroa teria "pesado" menos que o bloco de ouro, tirando a barra da sua posição inicial de equilibrio [...] e revelando, assim, que não era feita de ouro puro. [...] ele concluiu que a coroa não era feita de ouro puro, e sim de uma mistura de ouro e prata, já que seu "peso" dentro da água (peso aparente) era menor que o peso aparente do ouro [...] (TORRES et al., 2016, p. 132-133). 
Anacronismos pontuais à parte, a nosso ver o pequeno tratado galileano foi adequadamente transposto pelos autores para o Ensino Médio, permitindo que estudantes compreendam o experimento qualitativamente. Somam-se a imagem de uma balança hidrostática do século XVII, época de Galileu, e uma ilustração que representa as quatro situações experimentais descritas com o uso da balança: “(A) Coroa e bloco de ouro de massa iguais, em equilíbrio no ar; (B) dentro da água, a coroa tem peso aparente menor que o bloco de ouro; (C) coroa e bloco de prata de massa iguais, em equilíbrio no ar; (D) dentro da água, a coroa tem peso aparente maior que o bloco de prata" (TORRES et al., 2016, p. 133).

A seção "Princípio de Arquimedes" menciona o tratado Sobre os Corpos Flutuantes. Os autores "transformam" a escrita das proposições de Arquimedes a fim de apresentarem uma descrição do princípio em linguagem científica atual: o que é "mais leve" ou "mais pesado" no tratado é dito "menos denso" ou "mais denso" no livro didático. Faz-se um adendo (muito oportuno) sobre o uso do termo fluido por Arquimedes, já que o pensador se referia a líquidos, generaliza-se o conceito para líquidos e gases como feito no início do capítulo e, por fim, enuncia-se assim o princípio: "Todo corpo sólido mergulhado num fluido em equilíbrio sofre a ação de uma força vertical de baixo para cima, cuja intensidade é igual à do peso do fluido deslocado pela parte submersa do corpo" (TORRES et al., 2016, p. 135).

Os autores poderiam ter esclarecido que tanto o enunciado quanto as formulações matemáticas ulteriores não são produtos acabados no século III a.C. Pequenos detalhes à parte, o exemplar realiza uma transposição compreensível e bastante adequada do episódio histórico para o contex to didático.

\section{Física, de Guimarães, Piqueira e Carron}

Na seção "Em construção", que traz a "Biografia de um personagem importante para a Física", os autores apresentam "Arquimedes e a coroa do rei Hierão II", um recorte biográfico que identifica Arquimedes como "um dos maiores cientistas da Antiguidade" (GUIMARÃES; PIQUEIRA; CARRON, 2016, p. 250). Posteriormente, a seção sobre o Princípio de Arquimedes o traz como "inventor e matemático grego" (GUIMARÃES; PIQUEIRA; CARRON, 2016, p. 269).

Apesar do sutil anacronismo inicial, o recorte biográfico apresentado traz alguns aspectos positivos. Transparece o caráter cooperativo da atividade científica. Destaca-se o papel de Euclides na formação intelectual de Arquimedes e a relação deste com outros matemáticos, bem como sua associação ao rei de Siracusa. Certas referências históricas, portanto, subjazem a uma historiografia da ciência com fundamentos atualizados, contrapondo-se a visões individualistas e socialmente neutras. Os autores, de fato, estimulam o estudante a perceber a importância das influências recebidas por Arquimedes. A partir da leitura do recorte propõem o questionamento: "Qual a origem da habilidade de Arquimedes para formular problemas físicos usando conhecimentos de Geometria?” (GUIMARÃES; PIQUEIRA; CARRON, 2016, p. 250). Há recomendação para que o professor enfatize esse 
tipo de aspecto, denotando preocupação em relação à temática Natureza da Ciência, perceptível em orientações no manual do professor:

O fato de Arquimedes ter estudado em Alexandria com sucessores de Euclides foi bastante importante para sua formação e para sua habilidade em usar conceitos de Geometria para resolver problemas físicos. Aconselhamos aqui que você também dê destaque a outras características, como a curiosidade e a persistência, importantes para Arquimedes, mas que podem ser trabalhadas por qualquer pessoa (GUIMARÃES; PIQUEIRA; CARRON, 2016, p. 391).

Os aspectos positivos supracitados dão lugar a encaminhamentos questionáveis em passagens do mesmo recorte biográfico e em atividade subsequente a este. $\mathrm{O}$ exemplar apresenta a pseudo-história ventilada por Vitruvius (com detalhes acrescidos pelos próprios autores) como maior constituinte da biografia. Segue-se assim a narrativa biográfica exposta:

[...] Arquimedes foi instruído a realizar a tarefa sem estragar a coroa. Segundo essa história, ele não imaginava como proceder até que um belo dia, entrando em uma banheira cheia, notou que a água transbordava. Repentinamente ocorreu-lhe que a quantidade de água transbordada era igual, em volume, à parte do corpo nela mergulhada. Raciocinou então que, se mergulhasse a coroa na água, poderia determinar seu volume pela subida do líquido. Poderia mais ainda: comparar esse dado com o volume de um pedaço de ouro de igual peso. Se os volumes fossem iguais, a coroa seria de ouro puro. Se a coroa fosse feita de uma liga de prata (menos densa que o ouro), teria um volume maior. Entusiasmado com a descoberta, diz a história que Arquimedes pulou para fora da banheira, e, completamente nu, correu pelas ruas de Siracusa até o palácio real aos gritos de “Achei! Achei!'. Vale destacar que a nudez não perturbava os gregos daquela época tanto como perturba em nossa cultura atual ${ }^{10}$. Como Arquimedes falava grego, o que disse foi "Eureka! Eureka!" [...] (GUIMARÃES; PIQUEIRA; CARRON, 2016, p. 250).

Após o recorte biográfico, os autores sugerem ao estudante uma atividade que, pelo enunciado tão simplificado, parece soar como simples:

Leia o texto "Arquimedes e a coroa do rei: problemas históricos", de Roberto de Andrade Martins (disponivel em: $<w w w . p e r i o d i c o s . u f s c . b r / i n d e x . p h p / f i s i c a / a r t i c l e / v i e w / 6769 / 6238>$; acesso em: set. 2015), e discuta com seus colegas a possivel criação de mitos na ciência (GUIMARÃES; PIQUEIRA; CARRON, 2016, p. 250).

O encaminhamento proposto é profundamente inadequado. Transfere-se aos estudantes a responsabilidade de perceber, a partir da leitura de um texto acadêmico (?!), que

\footnotetext{
${ }^{10}$ Com essa frase, Guimarães, Piqueira e Carron pretenderam tornar aceitável que se considere Arquimedes nu pelas ruas de Siracusa. Nota-se, no entanto, que Vitruvius destaca o fato de Arquimedes correr nu, o que denota a excepcionalidade do ato, não a sua normalidade. A ressalva dos autores, portanto, está longe de contribuir com a desconstrução da visão esdrúxula que se tem de Arquimedes.
} 
a versão vitruviana contida no livro didático é questionável. Caso não realizem a atividade, restará para eles como verdade apenas a pseudo-história. E se, por outro lado, se dispuserem a realizar a atividade? O artigo de Martins (2000) é um texto acadêmico e não tem por públicoalvo estudantes da educação básica ${ }^{11}$. Nota-se, portanto, que a atividade proposta não é adequada. $\mathrm{O}$ conteúdo do artigo acadêmico precisa passar por uma transposição didática ${ }^{12}$ que o torne acessível aos estudantes. A necessidade desse processo parece ter sido ignorada, nesse caso, pelos autores do referido exemplar. É muito expressivo, ainda, o fato de não constar no manual do professor qualquer recomendação acerca de como essa atividade de leitura e discussão do texto acadêmico poderia ser conduzida ou mediada pelo professor. Estudantes e professor são deixados à própria sorte.

Posteriormente, o livro didático destaca: "A origem dessa força nos remete a Arquimedes de Siracusa (282-212 a.C.), inventor e matemático grego que constatou que um corpo imerso em água torna-se aparentemente mais leve" (GUIMARÃES; PIQUEIRA; CARRON, 2016, p. 269). Tangencia um viés empirista-indutivista, a referência a uma "constatação" do empuxo. Fenômeno e conceito se confundem.

Em seguida, no entanto, nota-se no texto disponibilizado para os alunos o reconhecimento de que a abstração e a interpretação desempenharam um papel importante no episódio em questão. Perde lugar a simples "constatação". Teria sido o raciocínio "altamente engenhoso" de Arquimedes - considerando mentalmente a inexistência de um corpo imerso em um fluido em equilíbrio - a implicar o princípio que leva seu nome: "Todo corpo mergulhado num fluido (líquido ou gás) fica sujeito ao empuxo, uma força vertical para cima, exercida pelo fluido, sendo a intensidade dessa força igual ao peso do fluido deslocado pelo corpo" (GUIMARÃES; PIQUEIRA; CARRON, 2016, p. 269).

É ausente ressalva de que essa redação para o princípio não remonta a Arquimedes. A lacuna pode estimular uma visão individualista da ciência, além de anacrônica, que supõe o conhecimento científico atual já proposto no século III a.C. Há margem para os estudantes pensarem que Arquimedes seria ainda responsável pelas expressões matemáticas ulteriores ao enunciado. Em parte, desde que o professor leia o manual a ele destinado, pode-se contornar esse problema com a referência dos autores à "beleza" no raciocínio de Arquimedes: não ter havido "uma conta sequer" (GUIMARÃES; PIQUEIRA; CARRON, 2016, p. 395). Por outro lado, a visão individualista é reiterada no manual e, caso não seja um profissional com conhecimento historiográfico e histórico, o professor facilmente reproduzirá equívocos.

Nas orientações dispostas no manual do professor, os autores sugerem a reprodução com os estudantes do raciocínio de Arquimedes:

\footnotetext{
${ }^{11}$ Convém lembrar, como já mencionamos, que Forato (2013), ao realizar uma atividade de formação docente, relatou dificuldade dos licenciandos em Física na leitura do artigo.

${ }^{12}$ Usamos a expressão "transposição didática” para a HFC no sentido de Forato, Pietrocola e Martins (2011).
} 
Sugerimos que você reproduza com os alunos o raciocínio de Arquimedes. Comece desenhando um recipiente com líquido em equilibrio. Agora, imagine uma porção de líquido que vai ser mentalmente retirada [...]. Como seriam as forças que o líquido ao redor da porção mentalmente retirada aplicaria nela? Como a porção $V$ estava em equilibrio, logo, o somatório das forças que o fluido em volta aplicava nela deve ter a mesma intensidade que seu peso, mas é aplicada em sentido contrário, impondo o equilibrio. Se na região de volume $V$, em vez de líquido tivermos outro corpo qualquer, da mesma forma, ela ficará sujeita à mesma força. $S e$ a porção de volume $V$ estiver totalmente submersa, o raciocínio permanece o mesmo. O raciocínio permite também descobrir em que ponto está aplicada a resultante das forças que o líquido ao redor aplica no corpo submerso: no centro de massa do volume de líquido deslocado, pois ele estaria em equilíbrio. A beleza dessa conclusão de Arquimedes é que ele não utiliza uma conta sequer para chegar até ela. É uma mostra de quão longe pode ir o raciocínio puro (GUIMARÃES; PIQUEIRA; CARRON, 2016, p. 395).

$\mathrm{Na}$ orientação ao professor transcrita anteriormente, o tom assumido pelos autores contraria fortemente a visão de "constatação", que tangencia a visão empirista-indutivista na versão disponibilizada para o aluno. Para que a visão distorcida não prevaleça, caberia ao professor percebê-la e problematizá-la ao abordar o conteúdo a partir desse exemplar.

\section{Física em Contextos, de Pietrocola e colaboradores}

A sensação de corpo mais leve quando estamos em uma piscina ou no mar serve de contexto para a apresentação da concepção contemporânea de empuxo: "Isso acontece porque a água exerce uma força de sustentação denominada empuxo, que age no sentido contrário ao da força peso. Essa força aparece sempre que um corpo está imerso em um fluido líquido como a água ou gasoso como o ar" (PIETROCOLA et al., 2016, p. 194). Não há uma abordagem histórica para o Princípio de Arquimedes. Registra-se apenas a afirmação:

O cálculo dessa grandeza foi definido por Arquimedes (o mesmo das alavancas). Segundo o matemático grego, quando um corpo é total ou parcialmente imerso em um fluido, sofre um empuxo igual ao peso do volume do fluido deslocado. Essa constatação ficou conhecida como princípio de Arquimedes (PIETROCOLA et al., 2016, p. 194).

O Princípio de Arquimedes é descrito com validade generalizada para fluidos. Seguindo essa afirmação, aparece a dedução da expressão para o cálculo do empuxo. A descrição hodierna do princípio e a formulação matemática da grandeza empuxo podem vir a ser entendidas, pelo modo como os autores escrevem, como construções individuais de Arquimedes. Diante da citação transcrita anteriormente, restaria ainda questionar: se, "como as outras forças que estudamos, a unidade de medida [da força de empuxo] é o newton (N)" (PIETROCOLA et al., 2016, p. 194), teria Arquimedes em seu suposto cálculo chegado a 
resultado cuja unidade homenageia um pensador situado cerca de dois milênios após sua existência? Mesmo não apresentando a versão implausível de Vitruvius, o exemplar poderia ser mais cuidadoso no que tange a aspectos históricos e de Natureza da Ciência.

\section{Física, de Bonjorno e colaboradores}

Embora não seja um aspecto imperativo para concluirmos sobre como o Princípio de Arquimedes vem sendo efetivamente abordado em sala da aula, é conveniente conjugarmos nossa apreciação a indicadores de como os livros aprovados no PNLD 2018 vêm sendo adotados no país. Pesquisa recente identificou que a coleção de Bonjorno e colaboradores (2016), de perfil mais tradicional, foi a mais adotada em vinte e um estados da federação (SCHIVANI; SOUZA; LIRA, 2020). Observa-se que essa coleção tem como ênfase exercícios quantitativos.

O exemplar traz na seção "Teorema de Arquimedes"13 uma afirmação em moldes da historiografia Pedigree. Atribui toda a paternidade do conhecimento sobre empuxo, sua precursão e verificação experimental ao pensador grego:

Foi Arquimedes quem primeiro constatou as características do empuxo que um fluido exerce sobre um corpo que nele esteja total ou parcialmente imerso. Nos seus experimentos, verificou que, quando um corpo mais denso que o fluido é mergulhado neste, o seu peso aparentemente diminui em um valor igual ao peso do volume do fluido deslocado (BONJORNO et al., 2016, p. 262).

Caso vislumbrasse uma introdução conceitual, seria adequada a menção a "características" e não ao empuxo em si, como compreensão hodierna. Entretanto, por "características" se apresentam no livro didático: direção, sentido do empuxo e seu valor dado pela expressão matemática $\mathrm{E}=\mathrm{dgV}$. A terminologia de ciência contemporânea é exposta nesse trecho como se já existisse no século III a.C. A referência a fluidos é uma atualização dos conhecimentos expressos por Arquimedes, que se referiu apenas a líquidos.

Um ponto positivo do trecho supracitado poderia ser a referência a experimentos realizados por Arquimedes, de modo que a concepção do empuxo não teria decorrido de um simples insight, meramente ao acaso, tal como expressa a pseudo-história vitruviana. Por outro lado, a citação se refere ao ato de constatar pelo experimento, o que remete a um viés

\footnotetext{
${ }^{13}$ Bonjorno e colaboradores utilizam “teorema”. Gaspar, como já citamos, afirma que o Princípio de Arquimedes não é, na verdade, um princípio, pois pode ser deduzido a partir da lei de Stevin. Se não é um princípio, o que é então? Essa eventual dúvida não é esclarecida por Gaspar. Em artigo acadêmico sobre a inserção didática desse conteúdo físico, Silveira e Medeiros (2009, p. 275) registram: "Um princípio se constitui em uma 'proposição posta no início de uma dedução, não sendo deduzida de nenhuma outra no sistema considerado' [...]. Ora, no texto de Arquimedes, Sobre os corpos flutuantes [...], é na Proposição 5, demonstrada a partir do Postulado 1 e das proposições que lhe antecedem e já foram provadas, que reconhecemos o famoso enunciado de Arquimedes. Dessa forma, do ponto de vista lógico, aquele enunciado é um teorema - 'enunciado demonstrado em uma teoria' $[\ldots]-\mathrm{e}$, portanto, não há que chamá-lo de princípio".
} 
empirista-indutivista. Deve-se notar, ainda, que Arquimedes não se valeu de argumentos empíricos na introdução à concepção que hoje chamaríamos de empuxo (ASSIS, 1996).

A referência histórica é reduzida a uma diminuta nota. Percebe-se um sutil anacronismo no emprego do termo cientista e estranha diferenciação entre cientista e físico/matemático: "Arquimedes (287 a.C. - 212 a.C.), cientista, físico e matemático grego. Estudou em Alexandria, onde conviveu com grandes matemáticos e astrônomos como Eratóstenes de Cirene" (BONJORNO et al., 2006, p. 262). Cita-se o convívio com Eratóstenes, mas não se explora a coletividade do processo de construção do conhecimento, uma vez que todo o conhecimento sobre empuxo é atribuído a Arquimedes isoladamente.

Não há uma abordagem histórica do Teorema. Observa-se, no entanto, que, ao apresentarem o conteúdo físico, os autores contemplam um potencial contra-argumento à versão vitruviana, caso desejassem citá-la e contestá-la: a tensão superficial da água.

Por fim, mesmo não apresentando o relato vitruviano, sugere-se ao estudante a leitura da obra de divulgação científica "Arquimedes: uma porta para a ciência" (BONJORNO et al., 2006, p. 277). A autora da obra referenciada, Jeanne Bendick, por sua vez, expõe a pseudo-história da ciência. Em resenha disponível no site Ciência à Mão da Universidade de São Paulo (USP), afirma-se:

[...] ele intuiu, durante um banho de imersão, que diferentes materiais causariam diferentes elevações do nivel da água na banheira [...]. A descoberta da solução do problema afetou de tal forma Arquimedes que ele saiu nu, gritando pelas ruas da cidade a palavra "eureca, eureca!", que quer dizer "achei!". O gênio da ciência aplicada era também um coração entusiasmado! [... $]^{14}$

Assim, embora no exemplar não haja referência ao episódio da coroa do Rei Hieron, esta ocorre na indicação de leitura ao estudante, a qual traz a narrativa pseudo-histórica.

\section{Conexões com a Física, de Martini e colaboradores}

Os autores generalizam a ação do empuxo para fluidos, tanto líquidos quanto gases, e ilustram sua atuação por meio de imagens do cotidiano. Adotando um viés empiristaindutivista, afirmam que o módulo dessa força é passível de observação em um sistema massa-mola vertical ora imerso na atmosfera terrestre, ora em água. O conceito de empuxo emerge de forma historicamente descontextualizada. Observa-se apenas a seguinte afirmação:

\footnotetext{
Atribui-se ao grego Arquimedes (287-212 a.C.) a primeira definição de empuxo: "Todo corpo mergulhado em um líquido sofre uma força denominada empuxo equivalente ao peso do líquido deslocado”. O peso do líquido deslocado pode ser calculado a partir do volume do líquido deslocado [...] (MARTINI et al., 2016, p. 203).
}

\footnotetext{
14 Disponível em: <http://www.cienciamao.usp.br/tudo/exibir.php?midia=liv\&cod=_arquimedes-umaportapara acienciajeannebendick>. Acesso em: 15 jun. 2020.
} 
Há implícita a indicação de que o conceito de empuxo foi uma construção histórica, não restrita a Arquimedes ("primeira definição"), o que favorece a ideia de ciência como cooperação. Por outro lado, observa-se que ao pensador é atribuído o uso do termo empuxo.

$\mathrm{Na}$ versão do aluno, não há qualquer narrativa sobre o episódio do problema da coroa. Já no manual do professor, na seção sobre o Princípio de Arquimedes, há a seguinte nota: "No Suplemento, você encontra a sugestão de um texto que aborda fatos históricos sobre Arquimedes e o suposto problema da coroa de um rei" (MARTINI et al., 2016, p. 203). De fato, o que se nota no Suplemento é apenas a referência para o texto: "Sugerimos a leitura do artigo 'Arquimedes e a coroa do rei: problemas históricos', de Roberto de Andrade Martins, publicado no Caderno Catarinense de Ensino de Física [...]” (MARTINI et al., 2016, p. 344). Segue o link. O exemplar se limita à indicação de leitura para o professor e sequer o motiva a fazê-lo. Não há sugestão do que se pode realizar considerando o artigo, embora a apresentação do manual indique auxílio ao professor para "selecionar conteúdos e atividades que complementem as escolhas de seu planejamento pedagógico" (MARTINI et al., 2016, p. 290). O encargo de uma transposição didática desse conteúdo histórico é delegado exclusivamente ao professor.

\section{Física, de Doca, Biscuola e Bôas}

Questionamentos sobre a flutuação de um navio e de uma bola de plástico em uma piscina reiteram, segundo redação científica contemporânea, a existência de uma "força vertical e dirigida para cima que os corpos recebem quando imersos na água, no ar ou em outros líquidos ou gases [...]" (DOCA; BISCUOLA; BÔAS, 2016, p. 275). Afirma-se que "seu nome é empuxo, tendo sido descrita por Arquimedes de Siracusa no século III a.C." (DOCA; BISCUOLA; BÔAS, 2016, p. 275).

Dá-se a entender que o conhecimento foi estabelecido individualmente pelo pensador, que supostamente descreveu essa força para líquidos e gases. Ele usou o termo "empuxo", segundo transparece pela indicação de que "o que realmente o celebrizou foi a lei do empuxo", perceptível em recorte biográfico subsequente, de cunho laudatório:

\footnotetext{
Arquimedes (287 a.C. - 212 a.C.) nasceu em Siracusa, na ilha da Sicília, cidade que na época pertencia à Magna Grécia. Em viagem de estudos a Alexandria (Egito), conheceu Euclides e seus discípulos, tornando-se entusiasta de sua obra. Determinou a área da superfície esférica, obteve com precisão o centro de gravidade de várias figuras planas, construiu engenhos bélicos de notável eficiência e também um parafuso capaz de elevar a água de poços e estudou o mecanismo das alavancas. O que realmente o celebrizou, no entanto, foi a formulação da lei do empuxo. [...] (DOCA; BISCUOLA; BÔAS, 2016, p. 275; grifo no original).
}

$\mathrm{Na}$ ausência de uma contextualização mais adequada, podem ser compreendidos como provenientes de Arquimedes a notação matemática apresentada e o enunciado atualizado que se refere a fluidos: "Quando um corpo é imerso total ou parcialmente em um 
fluido em equilíbrio [...]" (DOCA; BISCUOLA; BÔAS, 2016, p. 276). Ainda no recorte biográfico, identifica-se a influência de Euclides. Observa-se, no entanto, que o livro deixa passar a oportunidade de reforçar esse aspecto colaborativo, uma vez que não evidencia as relações entre o entusiasmo mencionado a respeito de Euclides e seus discípulos e a geometria euclidiana abundante no tratado Sobre os corpos flutuantes de Arquimedes.

Doca, Biscuola e Bôas não trazem uma abordagem histórica do Princípio de Arquimedes, mas uma passagem do texto poderia ter servido de mote para que isso ocorresse. Inicialmente, um exemplo acompanhado por uma ilustração parece relacionado à versão vitruviana do problema da coroa: "[...] quando o bloco (sem porosidades) é introduzido na jarra preenchida com água até o nível do seu bico, certo volume do líquido extravasa, sendo recolhido no recipiente lateral. O volume de água extravasado é igual ao volume do bloco [...]" (DOCA; BISCUOLA; BÔAS, 2016, p. 277).

Em seguida, há uma proposta de "verificação da lei do empuxo" que poderia ser relacionada à narrativa galileana. Uma figura inicial mostra o equilíbrio de uma balança no ar, e quando um "peso" posto do lado esquerdo é mergulhado em água, nota-se o desequilíbrio:

[...] verificamos certo desequilibrio da balança. Isso ocorre porque, ao ser imerso na água, o corpo de ferro recebe desta uma força vertical e dirigida para cima - o empuxo [...]. Supondo que a retirada de um massor do prato à direita tenha sido suficiente para recolocar o travessão na horizontal, podemos afirmar que a intensidade do peso desse objeto é igual à do empuxo recebido pelo corpo de ferro imerso na água (DOCA; BISCUOLA; BÔAS, 2016, p. 277; grifo no original).

Tanto no exemplo quanto na verificação, não há abordagem histórica, embora as circunstâncias apresentadas sejam profícuas para isso. O que se expressa, então? O pensador grego deteria, desde o século III a.C., a pompa de um conhecimento imutável, verificado pelos experimentos expostos, em um viés empirista-indutivista de acúmulo de provas, que praticamente desconsidera o arcabouço teórico subjacente.

A fim de atender às exigências legais, os autores poderiam, em conjugação com as ilustrações, fazer referência à balança hidrostática e inserir comentários sobre a versão galileana do episódio da coroa, em contraponto à versão pseudo-histórica, com a qual o estudante pode eventualmente se deparar em outras circunstâncias.

\section{Física aula por aula, de Barreto Filho e Silva}

O exemplar - o segundo mais adotado no país, segundo pesquisa recente (SCHIVANI; SOUZA; LIRA, 2020) - generaliza o atual conceito de empuxo para líquidos e gases. Menciona o teorema de Stevin e, como decorrência deste, afirma "que a origem do empuxo está na diferença de pressão sobre um corpo imerso em um fluido" (BARRETO FILHO; SILVA, 2016, p. 269). Refere-se ao que gera o empuxo segundo o paradigma científico atual. Segue-se, então, uma afirmação de cunho (pretensamente) histórico: 
Coube ao filósofo grego Arquimedes (287 a.C. a 212 a.C.), após vários experimentos, concluir que a intensidade do empuxo é igual à intensidade do peso do volume do líquido deslocado quando um corpo qualquer é colocado em um fluido. O chamado teorema de Arquimedes pode ser enunciado da seguinte forma: Em um corpo em contato com um fluido em equilíbrio, o empuxo é uma força vertical orientada de baixo para cima, cuja intensidade é igual à do peso do volume de fluido deslocado (BARRETO FILHO; SILVA, 2016, p. 270).

A conclusão inicial atribuída a Arquimedes envolve os conceitos de fluido e de empuxo. Refere-se a um conhecimento atualizado, previamente definido no livro. $\mathrm{O}$ enunciado do teorema não é atribuído explicitamente a Arquimedes. Porém, o início do trecho transcrito transmite tal impressão, sendo esta eventualmente estendida aos cálculos matemáticos apresentados. Não só o enunciado contemporâneo, mas também a formulação matemática do empuxo podem ser compreendidos como produtos científicos do século III a.C. e obras individuais de Arquimedes, remetendo a uma visão individualista da ciência.

A afirmação transcrita é antecedida pela representação de um experimento. Arquimedes não teria feito uso de um dinamômetro e de uma balança calibrados em newton, mas transmite essa impressão a imagem de um experimento com essas características e a afirmação subsequente de que ele chegou às suas conclusões "após vários experimentos". A expressão reforça a ideia de esforço no trabalho empírico, ao contrário do simples insight da versão vitruviana. Por outro lado, importa lembrar que a argumentação de Arquimedes no original Sobre os corpos flutuantes não é de natureza empírica. Assim, a informação é historicamente pouco adequada, bem como incorre em viés empirista-indutivista.

Nesse exemplar, na abordagem do Princípio de Arquimedes há, de fato, preocupação com aspectos históricos. Na seção "Lendo a Física" temos o destaque para a abordagem do episódio histórico intitulado "Arquimedes e a coroa do rei":

[...] vamos trabalhar com uma história muito difundida no ensino da Física: a da descoberta da falsificação da coroa de um rei por causa da água derramada de um recipiente. O resgate dessa história se deu por meio de um texto de Marcus Vitruvius (c. 80 a.C. - 15 d.C.), arquiteto romano, que descreve um suposto procedimento utilizado por Arquimedes (BARRETO FILHO; SILVA, 2016, p. 275).

O exemplar transcreve, citando Martins (2000), a versão vitruviana do episódio. Em seguida, três questões são propostas:

1. Quais são os dois metais com que a coroa foi confeccionada? Pesquise a densidade de cada um deles e determine a diferença de volume encontrada para duas coroas que tenham a mesma massa de $1 \mathrm{~kg}$. 2. Em sua opinião, o método utilizado por Arquimedes descrito no texto é plausivel? Tente estimar qual seria a diferença no volume de água deslocado pelas diferentes coroas.3. Junte seu grupo e faça uma pesquisa sobre o que é uma balança hidrostática. Em seguida, determine de que modo esse mecanismo pode ter auxiliado na conclusão de Arquimedes sobre 
Sugere-se que a atividade seja realizada em grupo. As duas primeiras questões propõem, em conjunto, uma problematização da versão vitruviana para o episódio. Informa-se a conversão do sextarius, unidade de medida utilizada pelos romanos, para litros. Os cálculos são simples, mas possivelmente a mediação do professor se faz necessária.

Observa-se que os autores optaram por não apresentar a versão galileana do episódio, contrastando-a com a versão pseudo-histórica. Ao contrário, intencionaram que esse movimento fosse realizado pelos próprios estudantes, a partir de questões que conduzem a esse objetivo. Mediante cálculos, os estudantes são, assim, levados ao questionamento da versão vitruviana: seria mesmo plausível o método descrito? Novamente, é provável que a mediação do professor seja necessária para a percepção da inviabilidade do suposto método ${ }^{15}$.

De fato, os autores recomendam a participação do professor na condução das atividades, por exemplo, construindo uma balança hidrostática com os estudantes. A terceira questão propõe que os estudantes pesquisem sobre esse instrumento e pensem a possibilidade de que ele tenha sido utilizado por Arquimedes na solução do problema. Sugere-se, assim, que os alunos cheguem, eles próprios, à versão galileana para o episódio.

A atividade proposta por Barreto Filho e Silva é bastante interessante no sentido de que os estudantes são motivados a uma atitude ativa na identificação da não plausibilidade do método descrito por Vitruvius. Não se trata, além disso, de uma simples apresentação passiva da versão galileana como contraste, mas sim de uma construção da percepção da balança hidrostática como alternativa à pseudo-história. Os estudantes, com o apoio da mediação do professor, assumem um papel ativo na construção do conhecimento.

Ao contrário de exemplares que simplesmente recomendam que o professor ou até mesmo o aluno leia o texto de Martins (2000), o exemplar de Barreto Filho e Silva realiza, de fato, uma transposição didática a partir do texto acadêmico. Deve-se pontuar, no entanto, que o interesse e a preparação do professor para a mediação das atividades são imprescindíveis, sendo um ponto de partida fundamental a leitura do texto de Martins. Na tarefa de construção da balança hidrostática, é imprescindível que o professor esteja preparado a fím de não conduzi-la sob um viés empirista-indutivista. O manual do professor poderia reforçar a importância dessas atividades e conter orientações sobre como mediá-las, destacando que incentivam o protagonismo do estudante e o desenvolvimento de uma postura crítica. De outra sorte, caso o estudante só leia a versão vitruviana transcrita no livro, mas não seja estimulado às atividades de problematização, é aquela versão que tomará como verdade.

\footnotetext{
${ }^{15}$ Não há uma problematização da narrativa no que diz respeito ao estereótipo de pesquisador excêntrico. Notase, aliás, que o livro didático não inclui o trecho dessa narrativa no qual Arquimedes corre nu e gritando. A exclusão desse trecho faz o estudante conhecer um Arquimedes menos exótico do que o representado por Vitruvius e torna a versão - como um todo fisicamente implausível - menos impactante e suspeita.
} 


\section{Considerações finais}

Identifica-se impacto explícito de discussões acadêmicas recentes, fundamentadas em aspectos histórico-filosóficos, sobre o Princípio de Arquimedes em livros didáticos do PNLD 2018. Esse impacto, conforme pudemos notar é, por outro lado, ainda incipiente. Boa parte dos exemplares adota uma abordagem tradicional do conteúdo, com algumas informações carregadas de distorções históricas e viés empirista-indutivista. Há em alguns a referência à pseudo-história vitruviana exclusivamente. No que diz respeito ao Princípio de Arquimedes, não estão de acordo com o papel didático atribuído à História da Ciência na legislação educacional e com as indicações acadêmicas especializadas.

Outras possibilidades têm alcançado os livros didáticos, ainda que de forma embrionária. Um exemplar (GUIMARÃES; PIQUEIRA; CARRON, 2016) apresenta a pseudo-história de Vitruvius ao aluno e o orienta a ler o artigo de Martins (2000) para conhecer a versão galileana. O artigo, no entanto, não é apropriado para um estudante da educação básica. Outro exemplar (MARTINI et al., 2016), sem que apresente narrativa sobre o episódio da coroa, recomenda ao professor o texto de Martins, mas não oferece ao profissional qualquer orientação sobre a transposição didática daquelas informações. Em ambos os casos, os exemplares se eximem de apresentar uma alternativa à pseudo-história. Transferem o encargo ora ao próprio aluno, ora ao professor. Um outro exemplar (YAMAMOTO; FUKE, 2016) também realiza procedimento análogo de sugestão de leitura para o professor em relação ao texto de Silveira e Medeiros (2009). Refere-se a este como uma atualização para o enunciado do empuxo. Mas, o que fazer se o próprio exemplar traz o enunciado tradicional e exemplos que, segundo o texto acadêmico citado, são concebidos à luz do viés empirista-induvitista? Ao professor parece ser atribuído novamente o encargo.

Alguns exemplares ensaiaram avanços robustos na transposição didática da HFC para esse conteúdo científico ${ }^{16}$. Dois exemplares (BARRETO FILHO; SILVA, 2016 e TORRES et al., 2016) buscaram, de fato, uma transposição didática do conteúdo históricofilosófico se valendo explicitamente do texto de Martins (2000) ou do texto de Martins (2000) acrescido da fonte primária de Arquimedes (ASSIS, 1996). Trazem avanços em termos textuais e apresentam atividades interessantes, as quais, se mediadas adequadamente, podem contribuir de modo efetivo para a inserção de aspectos histórico-filosóficos na abordagem do Princípio de Arquimedes. Um dos exemplares (BARRETO FILHO; SILVA, 2016), por meio de questões posteriores à versão de Vitruvius, tenciona que o estudante, auxiliado pelo professor, reconheça a implausibilidade do método nela descrito.

A análise crítica minuciosa demonstrou que ainda é frequente nos livros didáticos a presença da pseudo-história empirista-indutivista, bem como a apresentação historicamente

\footnotetext{
${ }^{16}$ São exemplos bem sucedidos de uma "tarefa hercúlea": “[...] realizar recortes significativos da História da Ciência, apropriados a contextos e objetivos educacionais específicos, inserindo-os em propostas articuladas aos conteúdos científicos. Esse processo demanda atenção a considerações expressas na legislação educacional e deve refletir critérios mínimos de qualidade em termos historiográficos” (HIDALGO et al., 2018, p. 120).
} 
descontextualizada do Princípio de Arquimedes. A lacuna em termos de contextualização histórica caracteriza a visão de ciência a-histórica. Pode transmitir a impressão anacrônica de que o enunciado do Princípio foi escrito por Arquimedes, contemplando componentes de uma entidade vetorial e os conceitos atuais de empuxo e de fluido. Pode estimular, ainda, uma visão individualista da ciência. Afinal, trata-se do Princípio de Arquimedes. Em exemplares que ensaiam alguma referência histórica, equívocos foram notados. O viés empiristaindutivista prevalece. Há, por exemplo, indicações de que, realizando experiências cuidadosas, Arquimedes descobriu uma maneira de calcular o empuxo. No entanto, não se nota, na construção de Arquimedes, a abordagem da força de empuxo com formulação matemática. A argumentação do pesquisador era de natureza geométrica, não empírica.

O que pode estar chegando ao estudante brasileiro? É relevante considerarmos que a escolha do "livro didático pode interferir em diversas dimensões da experiência escolar, por exemplo: na seleção de tópicos a serem abordados; nos enfoques historiográficos e filosóficos [...]" (SCHIVANI; SOUZA; LIRA, 2020, p. e20200011-6). Dispomos de dados sobre a distribuição do livro didático, mas não sabemos o que, de fato, está chegando ao estudante. Como vimos, alguns exemplares ensaiam iniciativas de abordagem histórico-filosófica desse conteúdo físico. Esse não é, contudo, o caso da coleção de Bonjorno e colaboradores (2016), a qual explicitamos na seção de análise dos livros didáticos ser a mais adotada no país. Já a segunda coleção mais adotada, a de Barreto Filho e Silva (2016), em dimensão diametralmente oposta, realizou uma transposição bastante adequada do artigo de Martins (2000) para o contexto escolar, tendo sido, segundo a nossa avaliação, um dos exemplares que obteve sucesso nesse sentido.

Consideramos que a análise realizada pode contribuir produtivamente por não ser uma consideração geral sobre as inadequações da História da Ciência presente nos livros didáticos, mas sim por trazer de maneira detalhada, por um lado, como a descontextualização se apresenta e, por outro, como os livros didáticos têm tentado repercutir discussões acadêmicas sobre um episódio histórico específico. É promissor notar iniciativas nesse último sentido (algumas bem sucedidas, outras nem tanto), uma vez que esses exemplos demonstram que os trabalhos acadêmicos não estão estanques, isolados do contexto escolar.

\section{Referências bibliográficas}

ALFOnSO-GOLDFARB, A. M. O que é História da Ciência. São Paulo: Brasiliense, 1994.

ACEVEDO-DÍAZ, J. A.; GARCÍA-CARMONA, A.; ARAGÓN, M. M. Historia de la ciencia para enseñar naturaleza de la ciencia: una estrategia para la formación inicial del profesorado de ciência. Educación Química, Cidade do México, n. 28, p. 140-146, 2017.

ASSIS, A. K. T. Sobre os corpos flutuantes, tradução comentada de um texto de Arquimedes. Revista da SBHC, Rio de Janeiro, n. 16, p. 69-80, 1996. 
BALDINATO, J. O.; PORTO, P. A. Variações da História da Ciência no Ensino de Ciências. In: ENCONTRO NACIONAL DE PESQUISA EM EDUCAÇÃO EM CIÊNCIAS, 6, 2008, Belo Horizonte. Atas... Belo Horizonte: ABRAPEC, 2008. p. 1-8.

BARRETO FILHO, B.; SILVA, C. Física aula por aula. Mecânica. São Paulo: FTD, 2016. V.1.

BONJORNO, J. R. et al. Física. São Paulo: Editora FTD, 2016. v. 1.

BRASIL, MEC. Base Nacional Comum Curricular. Brasília: MEC, 2015 (a).

BRASIL, MEC. Edital de convocação para o processo de inscrição e avaliação de obras didáticas para o Programa Nacional do Livro Didático PNLD 2018. Brasília: MEC, 2015 (b).

DAMASIO, F.; PEDUZZI, L. O. Q. História e filosofia da ciência na educação científica: para quê? Ensaio: Pesquisa em Educação em Ciências, Belo Horizonte, v. 19, p. 1-19, 2017.

DOCA, R. H.; BISCUOLA, G. J; BÔAS, N. V. Física. São Paulo: Saraiva, 2016. v. 1.

FORATO, T. C. M.; PIETROCOLA, M.; MARTINS, R. A. Historiografia e natureza da ciência na sala de aula. Caderno Brasileiro de Ensino de Física, Florianópolis, v. 28, p. 27 59, 2011.

FORATO, T. C. M. Preparação de professores para problematização da pseudohistória em materiais didáticos. Enseñanza de las Ciencias, Barcelona, v. Extra, p. 1316-1321, 2013.

FUKUI, A.; MOLINA, M. M.; VENÊ. Ser protagonista: Física. São Paulo: SM, 2016. v. 1.

GASPAR, A. Compreendendo a Física. São Paulo: Ática, 2016. v. 1.

GALILEI, G. La Bilancetta. Cadernos de História e Filosofia da Ciência, Campinas, v. 9, p. 105-107, 1986.

GIL-PÉREZ, D. et al. Para uma imagem não deformada do trabalho científico. Ciência \& Educação, Bauru, v. 7, n. 2, p. 125-153, 2000.

GONÇALVES FILHO, A.; TOSCANO, C. Física: interação e tecnologia. São Paulo: Leya, 2016. v. 1.

GUIMARÃES, O.; PIQUEIRA, J. R.; CARRON, W. Física. São Paulo: Ática, 2016. v. 1. 
HIDALGO, J. M. et al. A história da ciência (distorcida ou ausente) em livros didáticos: o conteúdo sobre o "Experimento de Torricelli" como estudo de caso. Alexandria, Florianópolis, v. 11, p. 101-124, 2018.

LUZ, A. M. R.; ÁlVARES, B. A.; GUIMARÃES, C. C. Física: contexto \& aplicações. São Paulo: Scipione, 2017. v. 1.

MARTINI, G. et al. Conexões com a física. São Paulo: Moderna, 2016. v. 1.

MARTINS, R. A. Arquimedes e a coroa do Rei: problemas históricos. Caderno Brasileiro de Ensino de Física, Florianópolis, v.17, n.2, p. 115-121, 2000.

MARTINS, R. A. Introdução: a História da Ciência e seus usos na Educação. In: SILVA, C. C. Estudos de história e filosofia das ciências: subsídios para aplicação no ensino. São Paulo: Livraria da Física, 2006. p. xxi-xxiv.

MATTHEWS, M. R. História, Filosofia e ensino de ciências: a tendência atual de reaproximação. Caderno Catarinense de Ensino de Física, Florianópolis, v. 12, n. 3, p. 164214, 1995.

PIETROCOLA, M. et al. Física em contextos. 1 ed. São Paulo: Editora do Brasil, 2016. v. 1.

SCHIVANI, M; SOUZA, G. F.; LIRA, N. Programa Nacional do Livro Didático de Física: subsídios para pesquisas. Revista Brasileira de Ensino de Física, São Paulo, v. 42, p. e20200011 1-10, 2020.

SILVEIRA, F. L.; MEDEIROS, A. O paradoxo hidrostático de Galileu e a Lei de Arquimedes. Caderno Catarinense de Ensino de Física, Florianópolis, v. 26, n. 2, p. 273 294, ago. 2009.

TORRES, C. M. A. et al. Física: ciência e tecnologia. 4. ed. São Paulo: Moderna, 2016. v. 1.

VIDAL, P. H. O. A história da ciência nos livros didáticos de química do PNLEM 2007. 2009. 103 f. Dissertação - Programa Interunidades em Ensino de Ciências, USP, São Paulo.

YAMAMOTO, K.; FUKE, L. F. Física para o ensino médio. São Paulo: Saraiva, 2016. v. 1. 